\title{
How Much Does Environmental Degradation Cost? The Case of Morocco
}

\author{
Lelia Croitoru*, Maria Sarraf \\ The World Bank Group, Washington DC, USA \\ Email: ^lcroitoru@worldbank.org
}

How to cite this paper: Croitoru, L. and Sarraf, M. (2018) How Much Does Environmental Degradation Cost? The Case of Morocco. Journal of Environmental Protection, 9, 254-265.

https://doi.org/10.4236/jep.2018.93017

Received: February 8, 2018

Accepted: March 25, 2018

Published: March 28, 2018

Copyright (๑) 2018 by authors and Scientific Research Publishing Inc. This work is licensed under the Creative Commons Attribution International License (CC BY 4.0).

http://creativecommons.org/licenses/by/4.0/

\section{cc) (i) Open Access}

\begin{abstract}
Environmental degradation is costly-to individuals, to societies and to the environment. This paper makes these costs clear in the context of Morocco, a country marked by rapid economic development and urbanization. Although Morocco has made impressive efforts to strengthen its policies and strategies to protect its environment and natural resources, environmental degradation is still an issue. Using the most updated methodology and data sources, the paper estimates that environmental degradation imposed costs on Moroccan society of about US\$3.9 billion, or 3.5 percent of the country's GDP in 2014. Water-related problems and air pollution are the most pressing challenges, followed by agricultural land degradation. Based on these findings, the paper provides guidance for an improved management of the country's environmental priority areas.
\end{abstract}

\section{Keywords}

Cost of Environmental Degradation (COED), Valuation

\section{Introduction}

Environmental degradation is a major concern in many countries. Industrial production often discharges pollutants into rivers, preventing the use of these resources for other purposes. Unsustainable agricultural practices reduce crop productivity and cause dam sedimentation. These and many other forms of environmental degradation cause real costs to the economy and to people's welfare. Yet, these costs often go unmeasured, and thus, their magnitude is unknown. Therefore, a country has typically insufficient information about the level of environmental damage, let alone to reduce or reverse that damage.

Since 2000, the World Bank has conducted a systematic effort to measure the cost of environmental degradation (COED) at the national levels in several 
countries of the Middle East and North Africa region. The COED ranged between as little as 2.1 percent to as much as 7.4 percent of the gross domestic product (GDP) for different countries [1]. This work has not only raised the countries' awareness on the magnitude of the environmental damage, but was also instrumental in increasing budgetary allocations for environmental protection in the region [2].

Morocco has the most competitive economy in North Africa [3]. In addition, over the past decade, the Government of Morocco has invested heavily to strengthen its policies to protect its environment and natural resources [4]. In this light, the National Sanitation Plan (Plan national d assainissement), the National Program of Municipal Waste (Programme national des déchets ménagers et assimilés), the Program against Diarrheal Disease (Programme de lutte contre les maladies diarrhéiques) and the National Action Program on Fight against Desertification (Programme d action national de lutte contre la desertification) are just a few examples of successful efforts conducted by the Government during this period.

Despite these efforts, economic development puts pressure on environment, through air, water and land degradation. Aware of these problems, the Government of Morocco requested the World Bank to conduct a comprehensive study that estimates in monetary terms the COED at the national level. This paper provides a methodology to estimate the COED and the results of its application in Morocco. The work has been carried out during 2015-2017, based on secondary information collected from Government institutions, national statistics and scientific literature [4].

\section{Objective and Scope}

This paper provides an order of magnitude of the COED at the national level in Morocco. The valuation covers impacts on the following environmental categories ${ }^{1}$ :

- Water. impacts of different water-related problems (e.g. dam sedimentation, groundwater overexploitation, wastewater discharge in rivers, wetland degradation) on the environment and economy; and the consequences of inadequate water supply, sanitation and hygiene on health.

- Air quality. impacts of ambient and household air pollution on human health, in terms of mortality and morbidity due to exposure to fine particulates (particulate matter with diameter less than 2.5 microns, $\mathrm{PM}_{2.5}$ ).

- Agricultural land: impacts of land degradation on productivity of croplands (e.g. due to erosion and salinization) and rangelands (e.g. due to clearing, desertification and overexploitation).

- Forests: losses of forest goods (for example, timber, firewood, and non-wood forest products) and services (such as watershed protection and recreation)

${ }^{1}$ Some of the following categories can overlap. For example, damages to coastal zone can derive from waste discharge in the sea. In these cases, the value of damages has been estimated and considered in one category only, to avoid double counting. 
due to deforestation and forest fires.

-Waste: damages from the inappropriate collection, transport, and disposal of municipal and hazardous waste on the environment and public welfare.

- Coastal zone: losses of fisheries and recreational opportunities due to unsustainable activities on the coast.

- Global environment. impacts of economic activities on carbon dioxide $\left(\mathrm{CO}_{2}\right)$ emissions in the atmosphere.

It should be noted that certain activities cause short-term impacts: for example, certain health problems caused by air pollution last from a few weeks to several months (bronchitis, respiratory symptoms). Other activities have long-term impacts: deforestation causes ecosystem losses that may take years to recover. This study estimates the value of both short-term and long-term impacts caused by activities occurring during the reference year. Thus, it measures the present value of current and future costs imposed by environmental degradation that occurred in 2014. The study uses a 6 percent discount rate [5] and a time horizon of 25 years, chosen as average time of a generation ${ }^{2}$.

The final estimate is then expressed in terms of percentage of the country's gross domestic product (GDP) for the year 2014. This makes it intelligible to both policy makers and the general population [6]. In addition, it allows for comparisons of COED estimates among different countries; and among different damage costs within the same country.

\section{Methodology}

For each of the seven environmental categories mentioned above, the study estimates the impacts of environmental degradation through several valuation methods. Table 1 provides a summary of these methods, while the following paragraphs briefly describe their application for specific impacts. For a detailed description of the valuation methodology, several publications are available [7] [8] [9] [10] [11].

The COED is estimated based on standard valuation techniques, with the specific approaches chosen based on data availability. When sufficient data are available, damages are assessed using demand curve approaches, as exemplified below:

- market pricing. to estimate losses of wood due to deforestation based on the producer's price or to value forgone benefits from re-using waste oil based on the local oil price.

- substitute goods method: to estimate losses of fodder due to deforestation, based on the price of barley, as fodder substitute.

- hedonic price method: to value the depreciation of land located in the proximity of dumpsites, based on differences in price of properties with similar characteristics.

${ }^{2}$ Assuming that a person of average age will benefit from environmental services for another 25 years. 
Table 1. Main impacts of environmental degradation and valuation methods used.

\begin{tabular}{|c|c|c|}
\hline $\begin{array}{l}\text { Environmental } \\
\text { categories }\end{array}$ & Main impacts & Valuation method \\
\hline Water & $\begin{array}{l}\text { Impacts on environment and economy } \\
-\quad \text { dam sedimentation } \\
-\quad \text { groundwater overexploitation } \\
-\quad \text { loss of wetlands } \\
-\quad \text { discharge of domestic and industrial wastewater } \\
\text { Impacts on health } \\
-\quad \text { diarrhea and malnutrition }\end{array}$ & $\begin{array}{l}\text { Restoration cost } \\
\text { Restoration cost } \\
\text { Change in productivity } \\
\text { Restoration cost } \\
\text { Cost of health }\end{array}$ \\
\hline Air & $\begin{array}{l}\text { Impacts on health } \\
-\quad \text { outdoor and indoor air pollution }\end{array}$ & Cost of health \\
\hline Agricultural land & $\begin{array}{l}\text { Cultivated lands } \\
-\quad \text { impact of erosion on rain-fed crops } \\
-\quad \text { impact of salinization on irrigated lands } \\
\text { Rangelands } \\
-\quad \text { impact of clearing, degradation and desertification of } \\
\quad \text { rangelands }\end{array}$ & Change in productivity \\
\hline Forests & Impacts of deforestation and forest fires & $\begin{array}{l}\text { Market price, price of substitute goods, } \\
\text { benefits transfer, restoration cost }\end{array}$ \\
\hline Waste & $\begin{array}{l}\text { Municipal waste } \\
-\quad \text { insufficient waste collection } \\
-\quad \text { groundwater pollution } \\
-\quad \text { depreciation of land } \\
-\quad \text { forgone electricity and recycling benefits } \\
\text { Hazardous waste } \\
-\quad \text { forgone benefits from re-using waste oil } \\
-\quad \text { health impacts from lead exposure }\end{array}$ & $\begin{array}{l}\text { Benefits transfer } \\
\text { Restoration cost (depollution) } \\
\text { Hedonic price } \\
\text { Opportunity cost } \\
\text { Market price } \\
\text { Cost of health }\end{array}$ \\
\hline Coastal zone & $\begin{array}{l}\text { - impact of overfishing } \\
\text { - } \quad \text { recreational losses due to beach degradation }\end{array}$ & $\begin{array}{l}\text { Change in productivity } \\
\text { Cost of travel }\end{array}$ \\
\hline
\end{tabular}

- change in productivity: to estimate the impact of land degradation on agricultural production, based on cause-and-effect relationships between erosion/salinization and agricultural yields.

- opportunity costs. to estimate forgone benefits from waste, based on their potential use value in electricity and recycling.

- cost of health: to estimate the cost of premature mortality due to air pollution, based on available evidence of causal relationships between exposure to $\mathrm{PM}_{2.5}$ and mortality; and the Value of Statistical Life-a concept widely used in environmental literature to reflect people's willingness to pay for a reduction in mortality risk [12] [13] [14] [15] [16].

When data are insufficient to apply demand-curve approaches, losses are assessed using cost-based methods. For example, losses due to siltation of dams, overexploitation of groundwater and discharge of domestic and industrial water are estimated through the restoration cost method, which estimates the value of damage through the cost of restoring the environmental benefits lost to degradation. In cases where such information was not available, the benefits transfer method is used, by applying results from studies undertaken in similar contexts. 
For example, estimating the deforestation damages to forest parks is based on value transfer of recreational benefits of a certain park with similar characteristics.

Despite the extensive range of valuation methods, their application is often difficult. First, the accuracy of the results decreases, as the valuation scope increases: estimates obtained nationwide are usually less precise than those obtained at the local or project level. Second, in some cases, the use of benefits transfer from other studies leads to imperfect estimates ${ }^{3}$. Third, the lack of data enables a partial estimate of some impacts (e.g. forest degradation), while other impacts cannot be valued at all-e.g. the effects of nitrates runoff on water quality, of dam sedimentation on water turbidity, of marine degradation on biodiversity. Therefore, the final results should be considered as orders of magnitude, which are often subject to underestimation. To reflect the uncertainty of the estimates, the paper provides ranges of values.

\section{Results}

The magnitude of the COED varies greatly among environmental categories, due to the diversity and intensity of many factors such as: sources of degradation, the natural resources affected, the population exposed, etc. Sometimes categories overlap, e.g. the impacts of dam sedimentation due to deforestation concern both water and forests. In such cases, these impacts were included in one category only, to avoid double-counting. The following paragraphs present the main valuation results for each category; a detailed description of each estimation can be found in [4].

\section{- Water}

With a renewable water availability of $700 \mathrm{~m}^{3} /$ capita [17], Morocco is already a water-scarce country. Several pressures (e.g. groundwater overexploitation, discharge of untreated wastewater, climate change and variability) affect water resources, causing a decline in water availability and quality. Groundwater overexploitation stands out as the most important problem, particularly in the watersheds of Souss Massa Draa, Tensift, Sebou and Oum Errabiaa, imposing an annual cost ${ }^{4}$ of US $\$ 451$ million (Figure 1). The discharge of industrial wastewater in water bodies is the second most significant problem, generating the need for additional treatment costs ${ }^{5}$ of about US $\$ 391$ million. Finally, inadequate water supply, sanitation and hygiene induce about 940 pre-mature deaths and 5.9 million episodes of diarrheal diseases annually, which cost society about US $\$ 305$ million. Overall, the total cost of water-related problems is estimated at US\$1.4 billion, or 1.26 percent of the GDP [18].

\footnotetext{
${ }^{3}$ Results from benefits transfer are usually less accurate than those of the original study. ${ }^{4}$ This is based on the cost of getting water from alternative sources, which differ from a watershed to another: desalination for Souss Massa Draa watershed; water transfer for Sebou; re-use of treated wastewater; and increasing dam capacity in Oum Errabiaa watershed.

${ }^{5}$ About 964 million $\mathrm{m}^{3}$ of wastewater are annually discharged in water bodies [19], of which only 493 million $\mathrm{m}^{3}$ are treated [18].
} 


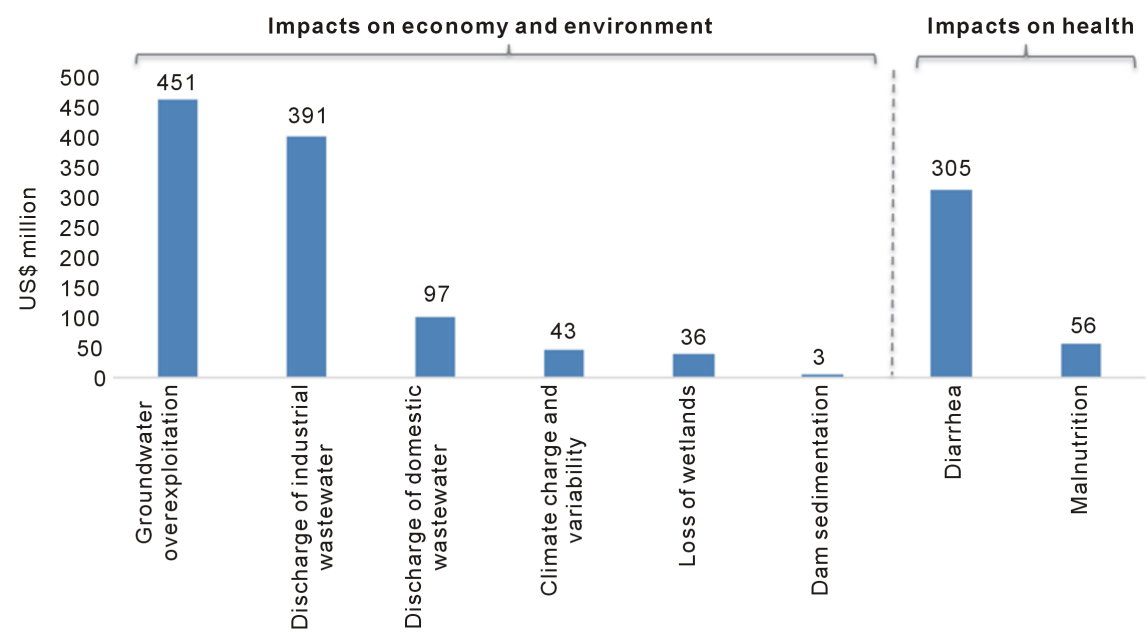

Figure 1. Cost of water degradation in Morocco. Source: based on [18].

\section{- Air}

Ambient (outdoor) and household (indoor) pollution affect negatively human health, due to exposure to fine particulates $\left(\mathrm{PM}_{2.5}\right)$. This exposure led to about 5,450 premature deaths in 2014 among adults, due to ischemic heart disease, stroke, lung cancer, and chronic obstructive pulmonary disease; and among children, as a result of acute lower respiratory infections. The mortality and morbidity cases due to this exposure led to an overall cost of air pollution of about US $\$ 1.15$ billion, or 1.05 percent of the GDP. Ambient air pollution is responsible for 75 percent of this cost (Figure 2) and it is particularly high in Casablanca, Marrakesh and Tanger, due to large populations exposed to high levels of $\mathrm{PM}_{2.5}$ concentration. Household air pollution is a significant problem for the rural households that use wood and coal for cooking and heating and accounts for 25 percent of the total cost. The most vulnerable groups for premature deaths from air pollution are adults over 55 years old, due to ischemic heart disease and stroke, and children under 5, due to acute lower respiratory infections.

\section{- Agricultural land}

Morocco has 9 million ha of cultivated land and 30.4 million ha of permanent rangelands. Human activities (overgrazing, deforestation, urbanization) and natural factors (e.g. climate change) are degrading these areas in multiple ways. On cultivated lands, erosion affects about 5.5 million ha of rainfed areas, while salinization affects 160,000 ha of irrigated lands; these losses are estimated at US $\$ 198$ million (Figure 3). Degradation affects also rangelands, through clearing (65,000 ha per year), desertification (103,000 ha per year) and overexploitation (30.2 million ha). These actions cause a complete loss of benefits on rangelands subject to clearing and desertification, and a reduction in productivity and other protective services on areas subject to overexploitation-with a cost estimated at US $\$ 393$ million. Overall, the total cost of agricultural land degradation is estimated at US $\$ 591$ million, or 0.54 percent of the $\mathrm{GDP}^{6}[20]$.

${ }^{6}$ This estimate refers only to the on-site impacts of land degradation. Among off-site impacts, the cost of dam sedimentation is considered in the water chapter. 


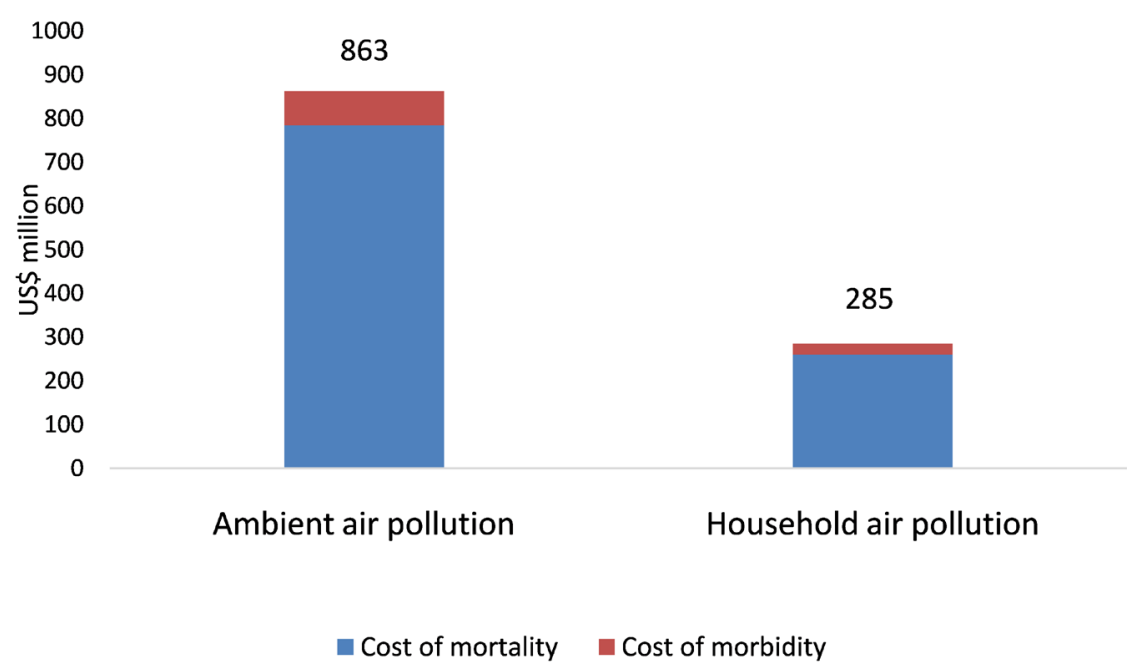

Figure 2. Cost of air pollution in Morocco. Source: based on [4].

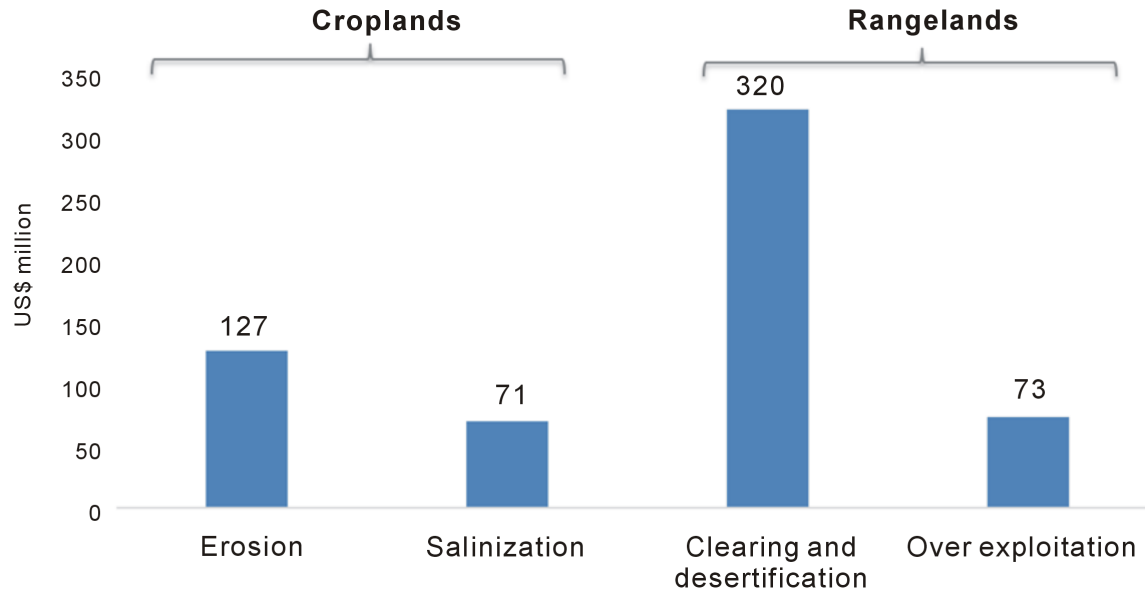

Figure 3. Cost of agricultural land degradation. Source: based on [20].

\section{- Waste}

Municipal waste management has considerably improved over the past decade, through increased coverage of waste collection and creation of sanitary landfills. Yet, waste management still generates some costs to society. Damages from municipal waste result from incomplete waste collection (with $20 \%$ of urban population not yet covered), groundwater pollution through leachate infiltration from unsanitary dumps; forgone economic benefits due to low recycling rates and land depreciation around open dumps. In addition, hazardous waste poses significant problems, such as environmental damages (e.g. leaking, burning) due to inappropriate disposal of waste oil; and health impacts (mental retardation) among children under 5 years old exposed to lead. Overall, the cost of inappropriate waste management is estimated at US\$434 million, or 0.4 percent of the GDP [21].

\section{- Coastal zone}

Extending on more than $3400 \mathrm{~km}$ along the Mediterranean Sea and Atlantic 
Ocean, coastal zone is very important for the country's economic development. However, concentration of tourism, maritime and fishing activities in certain areas causes pressures on living ecosystems and landscapes. Overfishing is a problem affecting a variety of fish types: e.g. sardines, swordfish, cephalopod and white hake; the difference between their optimal and current stocks, costing society about US $\$ 162$ million a year. Degradation of certain beaches affects national and foreign tourism through reduced recreational value, with a cost of about US $\$ 138$ million. Overall, coastal zone degradation leads to a cost of US $\$ 300$ million, or $0.27 \%$ of GDP [22].

\section{- Forests}

Moroccan forests cover 9 million ha, or 12.7 percent of the country's area [23]. They are subject to several pressures: clearing ( 880 ha per year), fires (3415 ha per year) and other forms of degradation, such as overexploitation for wood and fodder [4]. Overall, the losses of forest benefits-wood, cork, fodder, other non-wood products and recreation-are estimated at only US $\$ 4.8$ million. Fires account for about 75 percent of this damage, while deforestation stands for the remaining. It should be noted that this is a particularly underestimated figure, which does not account for losses of several forest benefits (e.g. mushrooms, acorns, cultural value), cost of dam sedimentation (which is reflected in "water" section), and cost of carbon emissions due to deforestation and fires (which is estimated in "global environment" section).

\section{- Global environment}

Over the past decade, economic development in the country led to an increase in greenhouse gas emissions ( $\mathrm{GHG})$, such as carbon dioxide $\left(\mathrm{CO}_{2}\right)$, sulfur dioxide $\left(\mathrm{SO}_{2}\right)$ and methane $\left(\mathrm{CH}_{4}\right)$. The 2016 Third National Communication to the United Nations Framework on Climate Change estimates the net emissions at 100.5 million $\mathrm{t}$ equivalent $\mathrm{CO}_{2}$ (or $3.1 \mathrm{t}$ equivalent $\mathrm{CO}_{2} /$ capita) in $2012^{7}$. The most important emitting sectors are energy (57 percent of the total), agriculture (21 percent) and waste (8 percent). Considering a range of carbon values between US $\$ 5.5 / \mathrm{t} \mathrm{CO}_{2}$ (the price on the European Union Emissions Trading System, [24]) and US\$30/t $\mathrm{CO}_{2}$ (the social value of carbon, [25]), the total damage on the global environment is estimated on average at US $\$ 1.8$ billion, or 1.6 percent of GDP. It is worth noting that Morocco's contribution to the global GHG emissions in the atmosphere remains low. For comparative purposes, $\mathrm{CO}_{2}$ emissions in Canada are $20.4 \mathrm{t}$ equivalent $\mathrm{CO}_{2}$ /capita vs. $3.1 \mathrm{t}$ equivalent $\mathrm{CO}_{2} /$ capita in Morocco.

\section{Total Cost of Environmental Degradation}

Overall, the COED to Moroccan's society was estimated at about US $\$ 3.9$ billion or $3.52 \%$ of GDP in 2014. In addition, carbon emissions caused damage to the global community in the order of $1.6 \%$ of GDP. The impacts of environmental

${ }^{7}$ The latest data available for $\mathrm{CO}_{2}$ emission (based on the Morocco's Third National Communication to UNFFCC, April 2016) are for 2012; as such it doesn't capture yet the benefits of various energy reforms introduced by Morocco (such as the removal of energy subsidy-introduced in 2013; or the recent investments in solar and renewable energy). 
degradation at the national level (national costs) appear to be more than twice as high as those at the global level (global costs) (Table 2).

Among national costs, water-related problems are the most important driver of degradation, followed by air pollution (Figure 4). Land degradation also causes significant damage, primarily due to erosion of croplands, and to conversion and desertification of rangelands. Waste is a relatively important component, mostly due to the inappropriate disposal of hazardous waste. The damage due to coastal zone degradation is considerably underestimated, as several polluting factors are captured within other categories ${ }^{8}$. Finally, the low cost of deforestation and forest fires is suggestive of the efforts carried out by the Government towards forest protection.

Table 2. COED in Morocco (2014) (US\$ billion and \% of the GDP).

\begin{tabular}{ccccc}
\hline & Lower bound & Upper bound & Average & \% of GDP \\
Water & 1.3 & 1.4 & 1.4 & $1.26 \%$ \\
Air & 0.7 & 1.5 & 1.1 & $1.05 \%$ \\
Agricultural land & 0.6 & 0.6 & 0.6 & $0.54 \%$ \\
Waste & 0.4 & 0.4 & 0.4 & $0.40 \%$ \\
Coastal zone & 0.3 & 0.3 & 0.3 & $0.27 \%$ \\
Forest & 0.0 & 0.0 & 0.0 & 0.0 \\
Cost to Moroccan society & 3.4 & 4.4 & 3.9 & $3.52 \%$ \\
Carbon emissions & 0.5 & 3.0 & 1.8 & $1.62 \%$ \\
Cost to global community & 0.5 & 3.0 & 1.8 & $1.62 \%$ \\
\hline
\end{tabular}

Source: based on [4].

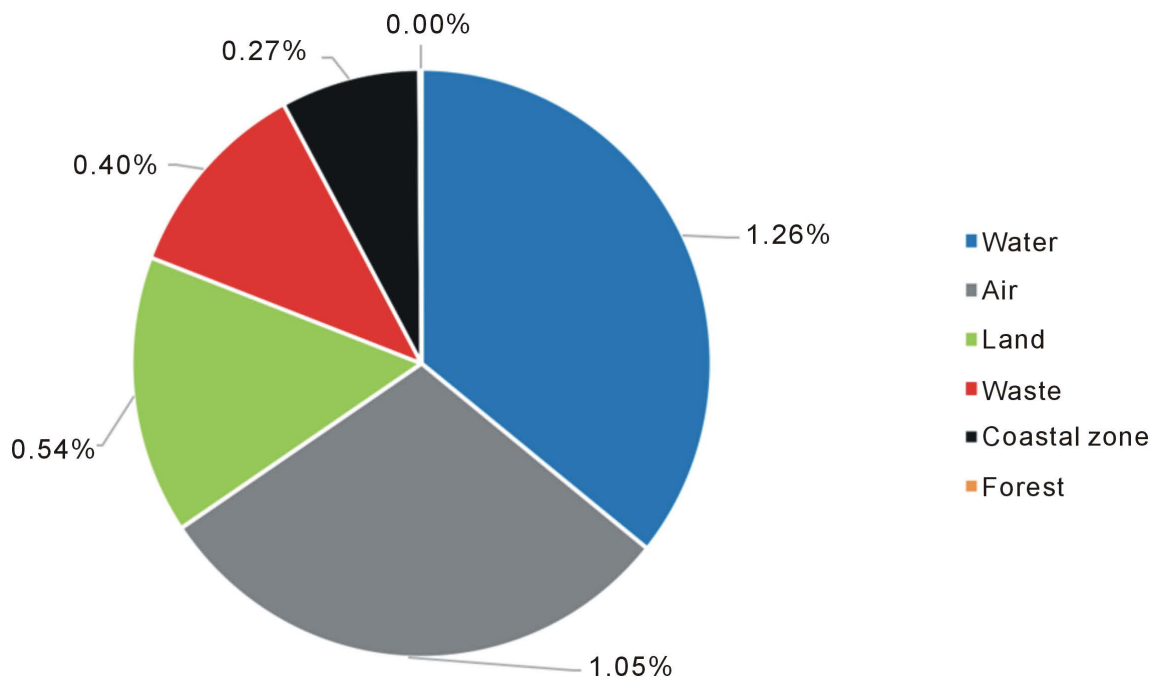

Figure 4. The COED in Morocco (\% of GDP, 2014). Source: based on [4].

${ }^{8}$ For example, the costs of air pollution, land degradation and water degradation have been accounted for in separate chapters. 


\section{Conclusions and Recommendations}

The study points out to the following conclusions and recommendations:

- The COED to Moroccan society is about 3.52\% of GDP, while the cost of greenhouse gas emissions to the global community is $1.6 \%$ of GDP. These results show that the impacts of environmental degradation at the national level are more than twice as high as those at the global level.

- Water-related problems are the most pressing challenges. This calls for actions to preserve water resources, by reducing groundwater overexploitation and discharges of untreated industrial wastewater in water bodies. Current efforts in this direction are already supported by the World Bank in the area of groundwater (e.g. supporting the basin agency Oum Er Rbia to establish "contrat de nappes"), industrial depollution (e.g. helping the Government prepare the National Plan of Industrial Depollution), and domestic wastewater (e.g. assisting with a sanitation project set up in the framework of the $\mathrm{Na}$ tional Sanitation Plan).

- Air pollution is another significant problem, particularly in large industrial cities like Casablanca, Marrakesh and Tanger. The most vulnerable groups to premature deaths from air pollution are adults over 55 years old (due to ischemic heart disease and stroke) and children under 5 (due to acute lower respiratory infections). Special attention should be targeted to these age groups when designing programs for reducing health impacts from air pollution [26].

- An emerging area is industrial/hazardous waste, for which inappropriate management is a cause of concern both in terms of environmental and health impacts. As children under 5 are most affected by exposure to lead, identifying the main hotspots and designing programs for improving the management of this type of waste are particularly important.

- Investing in environmental protection pays off. Over the past decade, the Government of Morocco has invested significantly in policies and programs to protect its environment and natural resources. As a result, the COED has decreased (in real terms) by over twenty percent between 2000 and 2014 [1].

\section{Acknowledgements}

This paper is a result of a comprehensive analytical work carried out by the World Bank, which estimated the cost of environmental degradation in Morocco. Ms. E. Strukova, Mr. A. Khattabi, Mr. A. Jorio, and M. S. Belghazi wrote several chapters of the analytical work. The authors gratefully acknowledge the support of the Ministry of Sustainable Development in Morocco, in particular Ms. R. Chafil, Mr. M. Maktit and Mr. S. Maliki, as well as the contribution of the Directorate of National Meteorology and the Ministry of Health. Special thanks are given to Mr. Benoit Blarel, Practice Manager, World Bank, for his support and constructive suggestions. 


\section{References}

[1] Croitoru, L. and Sarraf, M. (2010) The Cost of Environmental Degradation. Case Studies from the Middle East and North Africa. Directions in Development. The World Bank, Washington DC. https://doi.org/10.1596/978-0-8213-8318-6

[2] Arif, S. (2010) Implications for Policies, Investments and Institutions. In: Croitoru, L. and Sarraf, M., Eds., The Cost of Environmental Degradation. Case Studies from the Middle East and North Africa. Directions in Development. The World Bank, Washington DC, 147-160.

[3] World Economic Forum (2016) The Global Competitiveness Report 2015-2016. http://reports.weforum.org/global-competitiveness-report-2015-2016/competitiven ess-rankings/

[4] Croitoru, L. and Sarraf, M. (2017) The Cost of Environmental Degradation in Morocco. Environment and Natural Resources Global Practice Discussion Paper \#5. World Bank Group Report Number 105633-MA. Washington DC. [In French]

[5] World Bank (2016) Discounting Costs and Benefits in Economic Analyses of World Bank Projects. World Bank, Washington DC.

[6] Sarraf, M. (2004) Assessing the Costs of Environmental Degradation in the Middle East and North Africa Region. Environmental Strategy Notes 9. World Bank. Washington DC.

[7] Dixon, J.A., Scura, L.F., Carpenter, R.A. and Sherman, P.B. (1994) Economic Analysis of Environmental Impacts. Earthscan, London.

[8] Barbier, E. (2007) Valuing Ecosystem Services as Productive Inputs. Economic Policy, 22, 177-229. https://doi.org/10.1111/j.1468-0327.2007.00174.x

[9] Markandya, A. (2014) Economic Principles and Overview of Valuation Methods for Environmental Impacts.

https://www.czp.cuni.cz/Vzdel/letni_skola/program/Markandya_Economic\%20prin ciples\%20and\%20overview\%20of\%20valuation\%20methods\%20for\%20environmen tal\%20impacts.pdf

[10] Mendelsohn, R. and Olmstead, S. (2009) The Economic Valuation of Environmental Amenities and Disamenities: Methods and Applications. Annual Review of Environment and Resources, 34, 325-347. https://doi.org/10.1146/annurev-environ-011509-135201

[11] Johnston, R.J., Rolfe, R., Rosenberger, R.S. and Brouwer, R. (2015) Benefit Transfer of Environmental and Resource Values: A Guide for Researchers and Practitioners. Springer, Berlin. https://doi.org/10.1007/978-94-017-9930-0

[12] Lindhjem, H., Navrud, S. and Axel Braathen, N. (2011) Valuing Lives Saved from Environmental, Transport and Health Policies: A Meta-Analysis of Stated Preference Studies. Risk Analysis, 31, 1381-1407. https://doi.org/10.1111/j.1539-6924.2011.01694.x

[13] Biausque, V. (2012) The Value of Statistical Life: A Meta-Analysis.

[14] Viscusi, K. and Masterman, C.J. (2017) Income Elasticities and Global Values of a Statistical Life. Journal of Benefit Cost Analysis, 8, 226-250. https://doi.org/10.1017/bca.2017.12

[15] Narain, U. and Sall, C. (2016) Methodology for Valuing the Health Impacts of Air Pollution. Discussion of Challenges and Proposed Solutions, World Bank, Washington DC.

[16] Hunt, A., Ferguson, J., Hurley, F. and Searl, A. (2016) Social Costs of Morbidity Impacts of Air Pollution, OECD Environment Working Papers, No. 99, OECD 
Publishing, Paris.

[17] Secretariat d'Etat aupres du Ministre de l'Equipement, du Transport, de la Logistique et de l'Eau, Charge de l'Eau (2014).

http://www.water.gov.ma/ressources-en-eau/presentation-generale/

[18] Khattabi, A. and Croitoru, L. (2017) Water. In: Croitoru, L. and Sarraf, M., Eds., The Cost of Environmental Degradation in Morocco, Environment and Natural Resources Global Practice Discussion Paper No. 5, Chapter 3, World Bank, Washington DC. (In French)

[19] Direction de la Recherche et de la Planification de l'Eau (2014) The Sources of Water Pollution in Morocco. 24 p. (In French)

[20] Jorio, A. (2017) Land. In: Croitoru, L. and Sarraf, M., Eds., The Cost of Environmental Degradation in Morocco, Environment and Natural Resources Global Practice Discussion Paper No. 5, Chapter 5, World Bank, Washington DC. (In French)

[21] Jorio, A. (2017) Waste. In: Croitoru, L. and Sarraf, M., Eds., The Cost of Environmental Degradation in Morocco, Environment and Natural Resources Global Practice Discussion Paper No. 5, Chapter 7, World Bank, Washington DC. (In French)

[22] Belghazi, S. and Sarraf, M. (2017) Coastal zone. In: Croitoru, L. and Sarraf, M., Eds., The Cost of Environmental Degradation in Morocco, Environment and Natural Resources Global Practice Discussion Paper No. 5, Chapter 8, World Bank, Washington DC. (In French)

[23] Haut Commissariat aux Eaux et Forêts et à la Lutte Contre la Désertification (HCEFLCD) (2015) Ten-Year Plan 2015-2024. Haut Commissariat aux Eaux et Forêts et à la Lutte Contre la Désertification, Rabat. (In French)

[24] World Bank (2014) State and Trends of Carbon Pricing. ECOFYS, Washington DC.

[25] World Bank (2014) Guidance Note on the Social Value of Carbon in Project Appraisal. Internal Document, World Bank, Washington DC.

[26] Croitoru, L. and Sarraf, M. (2017) Estimating the Health Cost of Air Pollution: The Case of Morocco. Journal of Environmental Protection, 8, 13 p. 